\title{
The economic strategic cooperation between China -Thailand under the ASEAN-China Free Trade Area (ACFTA). In case of the situation between China -Thailand and the opportunities of Thailand after ACFTA completed.
}

\author{
Orathip Praisakuldecha \\ (School of Business Administration, South China University of Technology, Guangzhou510640, Guangdong, \\ China)
}

\begin{abstract}
China-ASEAN Free Trade Area is the arrangement for a free trade area (FTA) agreement between ASEAN and China that was designed to turn competition into complementation for the benefits of both sides such as trade relation, promote international trade and the implementation of zero tariff for import and export.This paper probes into the problems exist after CAFTA for Thailand, the present situation of Thailand that come from CAFTA and the opportunities of Thailand for trade sector, investment sector and finance sector.And, advancing some suggestion for solving the problems.
\end{abstract}

Key words: Thailand; China-ASEAN Free Trade Area; tariff; Tax; economic and trade

\section{Introduction}

The background of economic relation between China -Thailand. China -Thailand have a long time connection, In the past since Western Han dynasty and more pronounced in Sukhothai Kingdom and Ayutthaya Kingdom .There are trade between s counties, diplomatic connection, and Thai also received a technology to make a earthenware from China .In 1930-1950 ,Chinese people from Southern of China are immigrate to Thailand for building a new life and harmony living with Thai people. So, Thai and Chinese are closely relationship that have 7000 Oversea Chinese in Thailand about $14 \%$ of Thai people and about $1.7 \%$ of oversea Chinese around the world. And, China is the number 2 trading partner of Thailand . China's exports to Thailand amounted to $\$ 40.9$ billion or $20.3 \%$ of its overall imports. China-Thailand have many filed of cooperation together. First for Politics side, Thailand established diplomatic relations with the People's Republic of China on July 1, 1975 by Thailand - China proceeded smoothly on the basis of equality. They are respect and non-interference in the internal affairs of each other. And ,The under the principle of benefit in order to maintain peace, security and stability in the region. After the Cambodian war ,China is established diplomatic relations with all counties in ASEAN for extends to trade, economic and investment cooperation in the future. Thailand and China have relationship without any problems or conflicts and have visit from the top of the leader of both countries all the time . Current relations between Thailand - China is more closely together in all aspects as both bilateral or multilateral regional forums such as ASEAN-China Annual Consultation, ASEAN + 3, ARF, ASEM, etc. Thailand and China have agreed to develop relations and cooperation frameworks between countries for the all advantage together in the present and the future.Second for economics side, Thailand -China have signed an agreement to accelerate the reduction of tariffs on fruit and vegetables between Thailand - China that is the agreement between the Government of Thailand and the Government of the People's Republic of China on Accelerated Tariff Elimination under the Early Harvest Programs of the Framework Agreement on Comprehensive Economic Cooperation between ASEAN and China on June18, 2003 to reduce tax barriers to trade in goods, fruits and vegetables from both Thailand and China since October 1, 2003 that make the investment of China and Thailand are continuing increase and in 2014 China areinvest in Thailand is grains farm animals, motorbike, restaurant, and Thai massage .In the same way, Thailand are invest in China is light industry, chemicals industry, paper and plastic. Moreover, Chinese base metals industry investment has been approved by the Chinese government are 15 projects include construction business, trade ,bank, steel fabrication ,tourism, real estate, airlines, restaurants, and electronic parts . Third for travel side ,The government of Thailand and China have agreed on cooperation in tourism in August 1993 to promote cooperation in marketing and promoting of international tourism. However, the Chinese government has allowed Chinese people travel outside the country under the control of the government only. The first group that has allowed the Chinese people to travel are Thailand, Singapore and Malaysia .And the number of Chinese tourists visiting Thailand are increasing all the time and make more revenue for the country. In the same time, the number of Thailand tourists traveling to China are increasing .In 2014, the number of Thailand tourists visiting China is 613,100 people (times) and a number of Chinese tourists traveling to Thailand is 4.4221 million people (times). In the present, China is the country with the most tourists in Thailand. 


\section{ASEAN-China Relations}

The Association of Southeast Asian Nations, or ASEAN, was established on 8 August 1967 in Bangkok, Thailand, with the signing of the ASEAN Declaration (Bangkok Declaration) by the Founding of ASEAN, members: Indonesia, Malaysia, Philippines, Singapore and Thailand. Brunei Darussalam then joined on 7 January 1984, Viet Nam on 28 July 1995, Lao and Myanmar on 23 July 1997, and Cambodia on 30 April 1999, making up what is today the ten Member States of ASE The ASEAN.The vision of ASEAN as a concert of Southeast Asian nations, outward looking, living in peace, stability and prosperity, bonded together in partnership in dynamic development and in a community of caring societies. the ASEAN Member States have adopted the following fundamental principles, as contained in the Treaty of Amity and Cooperation in Southeast Asia (TAC) of 1976:

1. Mutual respect for the independence, sovereignty, equality, territorial integrity, and national identity of all nations;

2. The right of every State to lead its national existence free from external interference, subversion or coercion;

3. Non-interference in the internal affairs of one another;

4. Settlement of differences or disputes by peaceful manner;

5. Renunciation of the threat or use of force; and

6. Effective cooperation among themselves.

China became a member of the Economic Cooperation and World Trade such as APEC, GMS-EC, ASEM, ASEAN+3,etc.And ,more important is become the member of WTO that make China has the expansion of the trade.China has relations with the ASEAN have expanded rapidly. And, more than trade and economic activities, China-ASEAN cooperation has been broadened to cover environment, science and technology, nontraditional security areas and related legal issues. The cooperation between China and ASEAN is benefit with economically, providing them with an additional source of economic growth and the process of economic integration in the East Asian counties. China-ASEAN are relations in form of economic cooperation. There are relationship has been developing from economic to other areas of cooperation. There is competition between China and ASEAN countries in attracting foreign direct investment (FDI) and in exporting manufactured products to the same third-country markets. In order to avoid any disruption in China-ASEAN cooperation, China initiated the arrangement for a free trade area (FTA) agreement with ASEAN that was designed to turn competition into complementation for the benefits of both sides. China-ASEAN Free Trade Area is a free trade area among the ten member states of the ASEAN with China. On 4 November 2002 ,The framework agreement was signed in Phnom Penh, Cambodia, with the intention to start a free trade area among the 11 nations include China by 2010.The free trade area came into effect on 1 January 2010.

Table1: The model of reduction / elimination of tariffs on a regular ASEAN and China.

\begin{tabular}{|l|c|c|c|c|}
\hline \multirow{2}{*}{$\begin{array}{c}\mathrm{X}=\text { Applied } \\
\text { MFN tariff rate }\end{array}$} & \multicolumn{5}{|c|}{ Tax rates under the FTA between ASEAN - China. } \\
& 2005 & 2007 & 2009 & 2010 \\
\cline { 2 - 5 } & 20 & 12 & 5 & 0 \\
\hline $\mathrm{X}^{3} 20 \%$ & 15 & 8 & 5 & 0 \\
\hline $15 \% \mathrm{XX}<20 \%$ & 10 & 8 & 5 & 0 \\
\hline $10 \% \mathrm{X}<15 \%$ & 5 & 5 & 0 & 0 \\
\hline $5 \%<\mathrm{X}<10 \%$ & \multicolumn{2}{|c|}{ Fixed Tax rates } & 0 & 0 \\
\hline $\mathrm{X} £ 5 \%$ &
\end{tabular}

* Start reduces tax on July 1, 2005. * Most-favored-nation (MFN)

Source: Fisheries Foreign Affairs Division

The present situation of China -Thailand are relate of economic strategic cooperation under CAFTA. 1. After CAFTA is started that make the trade and international investment between China - Thailand are more interested.

In 2010 is the year that the cooperation between China - ASEAN are started. The trade of two side are developed. In the past,the agricultural products are the main export product between China and ASEAN especially Thailand. Before CAFTA is completed ,there are set the group of trade product. The establishment of China - ASEAN free trade agreement for providing an important platform for the development agricultural product processing industry in China ,except the traditional good trade. The CAFTA can force continue the development cooperation in the trade- service and international trade. In the present, China has invest in many industries in Thailand such as finance industry, transport industry, business industry, and catering industry. For the international investment side, China -Thailand make the law to support the investment between two countries. There are many investment cooperation such as port, public road and basis infrastructures .In the same time, China -Thailand should more invest in the public sector .It can see after CAFTA is 
completed .China-Thailand have to improve the trade- service agreement and the investment agreement to support the processing in trade -service and international investment.There are make China -Thailand have deep in the economic cooperation, prevent an external risk and two countries are realize the common progress and prosper it. For the foreign investment part,the motives for Chinese outward FDI are generally similar to those for FDI from other developing market economies (United Nations, 1993, Dunning, 1993, 2000 and Wall, 1997). China's outward FDI has increased rapidly for several motives. There are many push and pull factors that encourage Chinese companies to expand their business abroad in Thailand. China - Thailand and ASEAN are make agreement and law about the foreign investment. Thailand and China will continue their cooperation to enhance both land and water transportation, especially projects involving the Mekong River and high-speed railway construction. Thailand would like Chinese investors to expand their investment in Thailand, especially in the production of rubber, automotive parts, machinery, and electronics, and also in environment-friendly industries and renewable energy.

\section{CAFTA make China-Thailand 's market are diversification.}

After the opening reform, Chinese economy has kept rapid development for 30 years, which has already grown to third largest economies in the world. And, science and technology also have developed rapidly in China. China has transformed into a trade powerhouse and a world factory. Chinese products seem to be everywhere such as on the majority of tags, labels and stickers is "Made in China." The china's export are quite change from low quality product to high quality product. For ASEAN economics, there have 10 members. The economics of ASEAN members are not stay in same level .There have a developed country such as Singapore,$a$ developing country such as Thailand, and a undeveloped country such as Cambodia. According to this situation, the promotion of tax and tariff are advantage for all countries and make a competitions are fair for every country that trade between China -ASEAN. For example Thailand has many products are export from an agricultural products to technology products. Moreover, China -Thailand are cooperate about the technology of production in a longtime that make Thailand improve their skills and exchange the technology knowledge together. Thailand export to China is a computer components, circuit boards, plastic pellets, gems and jewelry, and rubber. And, Thailand import from China is an electric machine, machine, home electric appliance, computer and accessories, and chemicals. China is Thailand's second largest export market. China is also Thailand's largest importer of goods into the country in 2010 (Quinlan, Joe , 2007). China is a big country and economic of China is growth rapidly that make the some recourse in China can use in short term. So, China will bring the resource from other country .For the long term of Chinese resource that make import the resource from Thailand ,Thailand is the one of rich resource country in the world. In the same time, Thailand is import the technology product from China in high value such as computer, machine equipment, etc. So, when in Thailand market have product diversity that make Thailand have to improve theirs product to fight in the market. The diversity of product can make the consumers have more decision alternative and for the producer that have to develop their products to keep the customers and make the product differentiation for innovating the new type of product .Moreover, a tax and tariff is less or no is the advantage for people to select the import product in the reasonable price and also the advantage for productivity to export their product to China and ASEAN countries.

Table2 : The top 10 products of Thailand that export to China

\begin{tabular}{|l|c|c|c|}
\hline \multirow{2}{*}{ Product } & \multicolumn{3}{|c|}{ Value: Million bath } \\
\cline { 2 - 4 } & 2013 & 2014 & 2015 \\
\hline $\begin{array}{l}\text { 1.Computer, } \\
\text { accessories and } \\
\text { components }\end{array}$ & $179,792.1$ & $176,485.1$ & $164,908.2$ \\
\hline 2.Circuit boards & $80,110.2$ & $89,822.7$ & $109,244.8$ \\
\hline 3. Plastic pellets & $97,944.4$ & $107,754.7$ & $99,009.6$ \\
\hline 4.Gems and jewelry & $82,088.0$ & $83,797.7$ & $84,653.5$ \\
\hline 5.Rubber & $114,637.0$ & $88,809.9$ & $84,583.4$ \\
\hline 6.Cassava products & $61,387.8$ & $75,423.0$ & $76,302.6$ \\
\hline 7.Chemicals & $97,993.2$ & $85,620.5$ & $55,925.9$ \\
\hline 8.Rubber products & $72,306.3$ & $59,093.1$ & $34,942.9$ \\
\hline $\begin{array}{l}\text { 9.Wood and wood } \\
\text { products }\end{array}$ & $33,526.7$ & $35,480.6$ & $34,847.7$ \\
\hline 10. Finished Oil & $63,210.8$ & $47,809.4$ & $34,182.6$ \\
\hline
\end{tabular}

Source: The Customs Department (Thailand) : last update2015 
Table3 : The top 10 products of Thailand that import from China

\begin{tabular}{|l|c|c|c|}
\hline \multirow{2}{*}{ Product } & \multicolumn{3}{|c|}{ Value: Million bath } \\
\cline { 2 - 4 } & 2013 & 2014 & 2015 \\
\hline $\begin{array}{l}\text { 1. Electric machine and } \\
\text { components. }\end{array}$ & $156,892.3$ & $170,712.2$ & $217,167.3$ \\
\hline $\begin{array}{l}\text { 2. Machine and } \\
\text { components. }\end{array}$ & $123,326.4$ & $133,078.7$ & $151,334.6$ \\
\hline $\begin{array}{l}\text { 3. Home electric } \\
\text { appliance }\end{array}$ & $124,038.1$ & $135,132.0$ & $137,511.2$ \\
\hline $\begin{array}{l}\text { 4. Computer, } \\
\text { accessories and } \\
\text { components }\end{array}$ & $111,791.1$ & $104,583.9$ & $98,851.6$ \\
\hline 5. Chemicals & $75,097.8$ & $89,276.4$ & $92,115.8$ \\
\hline $\begin{array}{l}\text { 6. Automotive } \\
\text { accessories and parts. }\end{array}$ & $43,772.5$ & $43,089.7$ & $85,497.1$ \\
\hline $\begin{array}{l}\text { 7. Iron and steel } \\
\text { products }\end{array}$ & $63,896.1$ & $75,932.6$ & $77,471.7$ \\
\hline 8.Metal products & $35,684.4$ & $43,705.5$ & $45,740.3$ \\
\hline $\begin{array}{l}\text { 9. Jewelry, silver and } \\
\text { gold }\end{array}$ & $33,083.5$ & $24,008.6$ & $44,787.7$ \\
\hline $\begin{array}{l}\text { 10. Scrap metal and } \\
\text { products }\end{array}$ & $29,275.9$ & $33,235.4$ & $38,168.7$ \\
\hline \multicolumn{2}{|l|}{ Source: The Customs Department (Thailand): last update2015 } \\
\hline
\end{tabular}

The problems of the promotion in tax and tariff from CAFTA in trade development between China and Thailand.

The CAFTA that make the trade between China and Thailand are expend rapidly. The CAFTA is the one of biggest the free trade area in the world. CAFTA are continuing cooperation about 6 years ago. I would like to show about the problems that come from CAFTA between China -Thailand. Frist ,The product from China more Impact in Thai market . Form the trade between China and Thailand, China is a high population and an economic is also develop in many year ago but the China's labor cost are cheap and the consumed value of products in the domestic are high .Form this point and compare with ASEAN and Thailand's labor cost that make China have more advantages. China also have more production than Thailand and ,the technology level of China is developed as the developed country in the world. All of China's products have a great impact on the market of Thailand and other ASEAN countries and this is the worry to Thailand. Second, On the base of the framework of CAFTA ,There are not obvious about China's trade benefits to Thailand that make Thailand are happen a trade deficit. CAFTA make the economic cooperation between China-Thailand ,drive the trade in goods, trade in service and international investment of two countries for expanding in a long -term. The CAFTA 's mission is develop the economic together between China and ASEAN and have a ability to pass the economic crisis in the world .However, The Custom Department of Thailand show Thailand export to China in 2013 year as 824,672.21million bath, in 2014 year as 806,437.58million bath, and in 2015 year as 801,234.98million bath.And, Thailand import from China in 2013 year as 1,155,295.93million bath,in2014 year as $1,251,528.28$ million bath , and in 2015year as 1,403,176.69million bath. From Balance of trade that present is Thailand are a trade deficit with China because import value is more than export value and in the same time the other countries in ASEAN are also same situation. China -Thailand and ASEAN have the problem about trade are not balance. And ,This is the problem that effect the long -team economic in Thailand. Thailand and ASEAN should consider the gap between a level of export and import of countries. Moreover, the mission of no tax or tariff of CAFTA have to more understand and make the frameworks are clear. So, Thailand shouldprotect the economics' advantages and profits of the country.

Table4: The Import and export value of Thailand trade with China

\begin{tabular}{|l|l|l|l|}
\hline \multicolumn{4}{|c|}{ Trade value (Million bath) } \\
\hline & \multicolumn{1}{|c|}{2013} & \multicolumn{1}{|c|}{2014} & \multicolumn{1}{|c|}{2015} \\
\hline Import & $1,155,295.93$ & $1,251,528.28$ & $1,403,176.69$ \\
\hline export & $824,672.21$ & $806,437.58$ & $801,234.98$ \\
\hline $\begin{array}{l}\text { balance of } \\
\text { trade }\end{array}$ & $-330,623.72$ & $-445,090.70$ & $-601,941.71$ \\
\hline
\end{tabular}

The opportunities of Thailand from China- ASEAN free trade agreement.

1. The opportunity for trades sector.

In the present, China are a computer components, a circuit boards, a plastic pellets, a gems and jewelry, and a rubber that import from Thailand but Chinese are prefer in a fruit from Thailand(Table2). This opportunity of Thailand to export a fruit to China and have the promotion in tax under CAFTA. A fruit is a sensitive product. From Thailand's view, The logistic from Thailand to China are more convenience and more choices to select 
as by airfreight ,by shipping, and by land transport. First of all is the shipping is a main logistic to China .The shipping from Thailand to China have two directions are first is the Mekong river by using the Chiang Saen port in Chiang Rai province to o the port city of Xishuang banna in Yunnan Province or the port city of Nanning in Guangxi province for distributing the products to cities. Second by the Laem Chabang harbor through the South China Sea to Hong Kong.There are spend about 4 days and after that bring the products to smaller boats to the Nanhai port. And then the fruit will go to the Lishui Import Fruit Market in Guangzhou and distribution to other cities in Guangdong and other provinces such as Beijing, Shanghai and Xiamen. Secondly, the airfreight are transport the product that low production and high prices to airports in the cities of China such as Kunming, Chengdu, Shanghai, and Beijing. Third, The land transport by truck by using the route R9 from Mukdahan province through Laos ,Vietnam to the Yi Yong Ho in Guangxi, China. The total distance is about 1200 kilometers and take a short period about 2-3 days. There are the good opportunity for Thailand that distribute a Thai fruit to China .And, the price of Thai fruits have more the competitive advantages than many countries that come from the free trade agreement between China- ASEAN but the Thai manufacturer must keep the standard of qualities of their products.

Table5: Import of fresh fruit from Thailand

\begin{tabular}{|c|c|r|r|}
\hline \multicolumn{4}{|c|}{ Import of fresh fruit from Thailand. } \\
\hline Range & Country & \multicolumn{1}{|c|}{ Value of import(Milion Bath) } \\
\cline { 2 - 4 } & & $16,882.92$ & 2016 (Jan- May) \\
\hline 1 & China & $2,939.22$ & $7,220.28$ \\
\hline 2 & Vietnam & $2,870.77$ & $1,391.75$ \\
\hline 3 & USA & $1,795.42$ & $1,149.07$ \\
\hline 4 & Indonisia & $1,167.23$ & 1011.4 \\
5 & Peru & $32,260.22$ & 720.57 \\
\hline 6 & Other & $14,447.35$ \\
\hline
\end{tabular}

\section{The opportunity for investments sector.}

The trend of investment from Chinese investors from year2008-2014 in Thailand is an agricultural products, minerals and ceramics, light Industries/textiles, metal products and machinery, electric and electronic products, chemicals and paper and, services. First quarter in 2016 , China increase an investment budget is 61,740 million Yuan as 55.4 percent with compared to the same period last year and invest in ASEAN are increases as 44 percent or 2,300 Million USD. China has an objective to corporate with Thailand to be a production base and distribution to the ASEAN market among 9 countries and including other markets. In order to reduce logistics costs instead of export from China to directly. This al so the opportunity for Thailand to bring the money from foreign investors to invests in the domestic .There many reasons that attract the Chinese investors to invest in Thailand. First that come from Thailand is a center of trade, investment, production and export in ASEAN. Second, Thailand has a lot of resource and raw materials especially an agricultural product.Moreover, China and Thailand have a good relationship for a long time. The Board of Investment of Thailand shows in 2015, total investment of Chinese investors to invest in Thailand are more than 40,000 million bath and there are expected that in the next 3 - 5 years the Chinese private sector to invest in Thailand are more than 100, 000 million baht. The mission of Chinese investors that make Thailand as the product market of China. Thailand could be the production base for exporting to ASEAN countries and return to sell in China. In addition, There are using Thailand as a production base in some goods for exporting to Europe and America because some goods that made in China was barrier if export directly from China .

Table6: China Investment Projects Applying for Promotion Classified by Sector

\begin{tabular}{|c|c|c|c|c|c|c|c|c|c|c|c|c|c|c|}
\hline \multirow{2}{*}{ Sector } & \multicolumn{2}{|c|}{2008} & \multicolumn{2}{|c|}{2009} & \multicolumn{2}{|c|}{2010} & \multicolumn{2}{|c|}{2011} & \multicolumn{2}{|c|}{2012} & \multicolumn{2}{|c|}{2013} & \multicolumn{2}{|c|}{2014} \\
\hline & $\begin{array}{l}\text { No. of } \\
\text { Projects }\end{array}$ & Investment & $\begin{array}{l}\text { No. of } \\
\text { Projects }\end{array}$ & Investment & $\begin{array}{l}\text { No. of } \\
\text { Projects }\end{array}$ & Investment & \begin{tabular}{|l} 
No. of \\
Projects
\end{tabular} & Investment & $\begin{array}{l}\text { No. of } \\
\text { Projects }\end{array}$ & Investment & $\begin{array}{l}\text { No. of } \\
\text { Projects }\end{array}$ & Investment & \begin{tabular}{|c|} 
No. of \\
Projects
\end{tabular} & Investment \\
\hline Agricultural Products & 4 & 685.7 & 6 & $5,308.5$ & 10 & $2,014.4$ & 9 & $4,649.8$ & 6 & $1,262.7$ & 6 & 887.8 & 11 & $6,173.9$ \\
\hline Minerals and Ceramics & 1 & 89.0 & 2 & $4,591.7$ & 2 & 92.0 & 1 & 5.1 & 5 & $6,755.4$ & 1 & 126.9 & 5 & $5,275.3$ \\
\hline Light Industries/Textiles & 3 & 123.9 & 2 & 66.3 & 4 & 365.1 & 6 & $2,102.6$ & . & . & 3 & 106.5 & 4 & 633.5 \\
\hline Metal Products and Machinery & 5 & 119.7 & 4 & 203.1 & 6 & $1,375.8$ & 8 & $20,513.7$ & 15 & $2,543.6$ & 18 & $31,040.4$ & 19 & $10,505.9$ \\
\hline Electric and Electronic Products & 4 & 415.5 & $\cdot$ & $\cdot$ & 2 & 23.0 & 7 & $1,097.2$ & 4 & 168.5 & 9 & $5,511.1$ & 14 & $8,308.9$ \\
\hline Chemicals and Paper & 3 & 56.2 & 7 & $6,483.5$ & 5 & 697.1 & 4 & 118.0 & 10 & 830.8 & 5 & 584.9 & 16 & $1,525.6$ \\
\hline Services & 1 & 15.0 & 4 & $26,536.1$ & 2 & $6,131.0$ & 1 & 8.6 & 4 & $1,268.0$ & 3 & $4,273.0$ & 5 & $1,284.0$ \\
\hline Total & 21 & $1,505.0$ & 25 & $43,189.2$ & 31 & $10,698.4$ & 36 & $28,495.0$ & 44 & $12,829.0$ & 45 & $42,530.6$ & 74 & $33,707.0$ \\
\hline
\end{tabular}

Source: Thailand Board of Investment

\section{The opportunity for finances sector.}

Nowadays, China has sought to internationalize its official currency, the Renminbi $(R M B)$. RMB internationalization means that the renminbi goes beyond the jurisdiction of the People's Bank of China (PBC), and is accepted as the money of account, investment currency, and reserve currency in the markets of other 
countries and regions. According to the report of the Thailand International Bank. The Thai baht exchange RMB are a little fluctuate ,compare with US dollar . RMB is $0.5 \%$ of fluctuate rate and US dollar is $3 \%$ of fluctuate rate ).China -ASEAN have the Bilateral Currency Swap Agreement. China -Thailand are convenient to contact in finance and investments. Many companies allow Chinese companies trade with Yuan in ASEAN member countries .Moreover,the exchange rate between the RMB and money local of ASEAN countries are different between the buying and selling rate for motivating the entrepreneurs in this region are use RMB in trade more .This is a cooperation of economic that have a lot of advantage both ASEAN-China. Even though making RMB have the role with international trade are need time and have to cooperate together but make the ASEAN members have alternative currency for the international transactions. And, There are sing of Thailand will increase communicate and cooperate with China in the economic in the future .

\section{The suggestion for Thailand trade under CAFTA with China.}

According from CAFTA that make China -ASEAN have more strategic opportunities in economic relation. And, this is also the challenge of ASEAN countries for protect their own advantage and profit from the free trade agreement. For Thailand joined CAFTA about 6 years. The zero tariff between China and ASEAN are affect many factors both negative and positive in Thailand. For example, the development of production level, science and technology development, economic structure, product structure model, knowledge of zero tariff trade and other factors. Thailand and other countries of ASEAN should make more advantage form their resource in the country, improve existing industrial, improve the industry concentration degree,improve the level of management and optimize the allocation of resources. There can reduce the cost that make a strong advantage in international competition and make the country improve their potential to conform to the process of China ASEAN Free Trade Area .Moreover,Thailand should improve the product structure because China's exports to Thailand is both low price products, and high price products but the most export products of Thailand to China are low price products. Thailand should use own advantages to expand trade with complementary products, increase potential on the structure of import and export products ,reasonable adjustment to the competitive products, and Increase exports the high-value products. There are help Thailand and ASEAN counties get more benefit and reduce trade deficit from free trade agreement with China.

\section{Conclude}

China initiated the arrangement for a free trade area (FTA) agreement with ASEAN that was designed to turn competition into complementation for the benefits of both sides. There are call China- ASEAN free trade agreement or CAFTA. The relationship of China - Thailand that make relate of economic strategic cooperation under CAFTA are First , the trade and international investment between China - Thailand are more interested. China has invest in many industries in Thailand such as finance industry, transport industry, business industry, and catering industry. Second, China-Thailand 's market are diversification. There are export many products from Thailand and Thailand is import many products from China as a lot. Thailand has a lot opportunities from CAFTA are cover the trade sector, investment sector and financial sector that make Thailand's economic is developed and cooperate with China in many level. But CAFTA has made the problem with Thailand. Frist, the product from China more Impact in Thai market that come from China has more power in the production than Thailand and labor cost also cheap. Second, The value of export and import of Thailand with China is different that make Thailand has a trade deficit with China. So, Thailand and ASEAN should make more advantage form their resource in the country, existing industrial, improve the industry concentration degree, optimize the allocation of resources, improve the level of management. There are can reduce the industrial cost, further emancipate the productive forces that make a strong advantage in international competition and make the country improve their potential conform to the process of China ASEAN Free Trade Area. For, Thailand have to increase the product value. There are help Thailand and ASEAN get the advantage from free trade agreement with China. China-ASEAN Free trade Agreement is economic relation that power to develop the international trade and investment.

\section{References}

[1]. 张美慧朱明侠(2015),上海自贸区可以为泰国企业带来哪些商机.《经济师)2015 年 5 期。(pp31-33)

[2]. 张西勇. 鲁西北平原农村土地流转现状及问题与对策——基于聊城市 29 个村庄的调查. 国土资源科技管理。2013(5)李璐. 自贸区里的泰中贸易商机.进出经济人 2010 年第 1 期(P30-31)

[3]. Zhang Li xia.Development and Prospect of Economy and Trade between China and Thailand under CAFTA(2012)AROUND SOUTHEAST ASIAVol.12(pp17-20)

[4]. ShenHongfang,The Economic Relations between China and Thailand under the Context of CAFTA: An Assessment.Chinese Studies 2013. Vol.2, No.1, 52-60

[5]. Kim WengWillam Choy Yen Ming Zhang, (2011),"Economic relations between China and ASEAN: 1970-2010", Chinese Management Studies, Vol. 5 Iss 1 pp. $20-34$

[6]. Wang, Y.-Z. (2012). "The impact of CAFTA on China-ASEAN relationship: An evaluation from strategic perspective. Southeast Asian Affairs (Xiamen), 1, General Serial No. 149, 9-20.

[7]. Sompop, M. (2009). Thailand-China cooperation in trade, investment and official development assistance.URL(lastchecked20July2012).http://www.ide.go.jp/English/Publish/Download/Brc/pdf/01_thailandandchina.pdf 